\title{
NHP2 wt Allele
}

National Cancer Institute

\section{Source}

National Cancer Institute. NHP2 wt Allele. NCI Thesaurus. Code C152095.

Human NHP2 wild-type allele is located in the vicinity of $5 q 35.3$ and is approximately $5 \mathrm{~kb}$ in length. This allele, which encodes H/ACA ribonucleoprotein complex subunit 2 protein, plays a role in both ribosome biogenesis and telomere maintenance. Mutation of the gene is associated with autosomal recessive dyskeratosis congenita type 2 . 